\title{
Opera and Drama in Ravel ${ }^{1}$
}

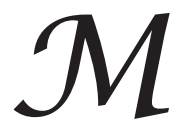

aurice Ravel's operatic works have not been fortunate. Anyone even slightly interested in music knows Ravel as the author of Boléro, the Rapsodie espagnole and Daphnis et Chloé. And yet his two astonishing operas, L'heure espagnole and L'enfant et les sortilèges, are still fairly obscure. They are shown very rarely in the theater, and were it not for recordings and radio broadcasts over the last decade, they might well have remained the sole property of musicologists. The lack of interest in these two masterpieces on the part of opera houses in the West is due in part to their technical difficulty. Though short, both operas require large expenditures and complicated props. The vocal parts demand virtuosos, but afford singers little opportunity to shine in full-blown, impressive arias. But the lack of interest can also be ascribed to the profound incomprehension, or rather the erroneous perceptions, of music critics. L'heure espagnole is usually put down as an amusing musical farce, L'enfant et les sortilèges as a fairy tale for children. In a small monograph on Ravel (subtitled "A Book for Young Readers"), published in Leningrad in 1964, Aleksandr Stupel, the author, rehearsing the usual dicta of French critics, actually calls L'enfant et les sortilèges a children's opera, which is like calling Lolita a children's novel just because the title character is a child.

The two operas were created nearly twenty years apart. They differ greatly in conception, in structure, and in the character of their music. But they do have a common denominator: the attempt to delineate the situation and personality of the characters not by musically illustrating the text (as in the operas of Richard Strauss), and not by combining text and music in one (as in Debussy's Pelléas et Mélisande), but through music that conveys a subjective, psychological quality (with reference to the characters singing) that seemingly contradicts the "objective" data of the libretto or the utterances of the characters themselves. The most telling example is the first

1 Translated by Richard Taruskin. Originally published as "Opernaia dramaturgiia Ravelia" in Novyi zhurnal, no. 94 (1969): 115-25. 
appearance of Concepcion, the heroine in L'heure espagnole. The everyday, prosaic recitative with which she addresses her husband the watchmaker is accompanied by a passionate, arching phrase from a solo cello. One English critic, probably Ernest Newman, thought that this seemingly unsuitable accompaniment was supposed to represent the ardent attachment of husband and wife. There is a simpler explanation. As it does throughout the opera, the musical commentary here conveys the subjective emotions of the character singing. In this case, Concepcion's whole being is suffused with anticipation of her coming rendezvous with her lover, the poet Gonzalve. That is what the cello is singing about, and the recitative the actual character sings - a reminder to her husband to wind the town clock-is just her outward prosaic manner, as it appears to the unobservant world.

The humorist and parodist who wrote under the pseudonym FrancNohain long wondered why Ravel thought his somewhat cynical comedy L'heure espagnole, written in a complicated variable meter and full of puns, was a fit libretto for an opera. Franc-Nohain's own conception was nothing like Ravel's opera. The bored wife of a watchmaker from Toledo has started up a romance with an affected, pretentious young poet. Having gotten her husband out of the house, Concepcion listens at length to the poet's passionate effusions, but it gradually dawns on her that for him the main thing in love is not love, but its literary possibilities. And yet Concepcion simply cannot let her chance of deceiving her husband go by! She has another admirer, the fat banker Don Inigo Gomez. But this stout banker, whom Concepcion has had brought to her room hidden inside a huge wall clock, has gotten stuck inside the clock and cannot take advantage of his unanticipated good fortune. The heroine weeps in frustration (and out of ungratified desire). But at the last minute she notices the muscular shoulders of the modest, bashful mule driver Ramiro, who throughout the action has been obediently fulfilling her whims, moving heavy clocks containing admirers from place to place. The mule driver has better luck than the poet or the banker. Or so the characters say, addressing the audience in the opera's epilogue: "Such is the moral of Boccaccio: The most able lover beats them all. In the game of love sooner or later it will be the driver's turn."'

2 C'est la morale de Boccace:

Entre tous les amants, seul amant efficace,

Il arrive un moment, dans les déduits d'amour,

Où le muletier a son tour! 
And that's it. As the author of the play himself observes in the epilogue, his characters are sketchy, one-dimensional puppets: the selfimportant banker, the precious poet, the dimwitted watchmaker of a husband, the naive simpleton Ramiro. But how these puppets come to life, take on depth, become human through Ravel's music! The male characters display a chivalry and idealism on which the author of the comedy surely never counted. Strange as it seems, the new dimensions introduced by the music do not contradict the text but reveal it from a new angle. The tenderness toward his wife and the affectionate turns of phrase in the watchmaker's part make the role more attractive and affecting than the stereotyped, mercilessly ridiculed cuckold portrayed by Franc-Nohain. The poet Gonzalve, in Ravel's musical incarnation, is truly seized with creative fervor. At the same time he is some sort of parodied reductio ad absurdum of Bryusov's Poet, for whom "this life of ours is just a thing / about which poets brightly sing." ${ }^{3}$ His languid, super-Spanishy airs at once embody and parody his passion. But he so exhausts himself in these melodies, and with such rapture tries to turn them into literature, that there is nothing left of him for Concepcion. She has been nothing but a stimulus to engage his essential modus operandi, literature. The woman he loves hurls herself relentlessly into his embrace, but Gonzalve is already working on the poetic elaboration of the blissful moments he in fact has had no time to experience. Is this parody? Farce? Yes, of course, but on another level the operatic treatment has granted us a profound insight into the sources and nature of artistic creation.

The fat, funny banker has flirted with a saucy mistress and ended up looking a fool. What, you may ask, could be more trite? But even here, Ravel finds a way to infuse the part of the clock-stuck Inigo with all the tenderness and sympathy one could wish for. The orchestra accompanies the banker's singing with a sort of jingling, intoxicating waltz, pulverized by unexpected pauses. It is as though within the heavy, aging body of the banker an enraptured, romantic youth were imprisoned, unwilling to surrender, thirsting for something, dreaming of something. Once again, through music, a banal scene is transformed into a most compassionate commentary on youth and age. And, finally, the sympathetic, naive

3 “Все в жизни лишь средство / Для ярко-певучих стихов” (Valery Bryusov, "Poetu"). 
driver (a dense bumpkin in Franc-Nohain's version) becomes, with the help of Ravel's music, the embodiment of gentle, manly benevolence and gallantry.

There remains, of course, Concepcion herself. Having humanized the male characters, Ravel seems not to have treated his heroine very kindly. And in truth, if in Franc-Nohain's comedy the distribution of forces was even-five amusing windup toys-in Ravel's opera we see four sympathetic idealists plus the same Concepcion as in the comedy, thinking of nothing except how to deceive her husband, no matter with whom. Her main aria is a despairing lament that fate has prevented her from fulfilling this plan, the composer making no concessions to her in the way of orchestral "extenuations." Can we therefore accuse Ravel of some kind of hidden misogyny and suspect him of harboring ideas about the essential nature of the female sex that were fashionable at the time of L'heure espagnole-ideas on the order of Przybyszewski or of certain plays by Leonid Andreev? Perhaps so, had Ravel not written an orchestral introduction to the opera that amounts in my view to a musical portrait of the heroine.

In the literature on Ravel, the introduction to L'heure espagnole is looked upon as an ingenious depiction of the watchmaker's shop. Critics have written a lot about the ticking pendulums, cuckoo clocks, music boxes, whirling toy ballerinas, and tweety birds virtuosically rendered by Ravel's orchestra. All of this is there in the music, but the sonic ornaments that have so delighted critics serve as but an adornment to the core of the introduction: a glum, monotonous five-bar phrase that runs through all the music at the beginning of the opera and that twice rises up into something like an outburst of despair. It would be hard to find in all of music a more perfect embodiment of ennui and tedium (the closest parallels: the introduction to Ravel's other opera, which depicts a bored child, and one of the Véritables préludes flasques by the musical humorist Erik Satie, where he wanted to convey the whimpering of a dog locked up in a house). But who is doing the whimpering and pining in the Toledo watchmaker's shop? Not the good-natured owner, who is always satisfied with his business, his clients and, to be sure, "himself, his dinner, and his wife."4 The one languishing amid all this tinkling and ticking is the watchmaker's

4 A. Pushkin, Evgenii Onegin, chap. 1, stanza 12 (lines that have become proverbial about cuckolds).-Ed. 
wife, who in this reading of the introduction suddenly appears as a cousin of Katerina Izmailova in Shostakovich's opera. Only where Shostakovich has Leskov's bored heroine start love affairs, feed her father-in-law poisonous mushrooms, throttle a child, ${ }^{5}$ drown her rival in the river, and end her own life in a suicide (and in addition to all of that, according to the composer's plan, indict all of tsarist Russia), Ravel's Spanish-French heroine is content with the first step-the affairs, without sacrificing anyone's life and without indulging in tragic finger-pointing. In this case Ravel's conception is of course the more true to life. If my interpretation of the introduction is correct, Concepcion's frivolity is explained and, in its way, justified by the orchestra, even before her first appearance on stage.

The bewitching melodies in L'heure espagnole are mainly assigned to the instruments of the orchestra. The poet Gonzalve is given a few passionate Spanish melodies, but they are obvious parodies of the pseudoSpanish style in nineteenth-century operas. Only in the extended final quintet in habanera rhythm do the singers finally get a chance both to sing real tunes and to distinguish themselves with virtuoso coloratura ornaments while the orchestra is relegated to the role of rhythmic accompaniment. In building his whole opera on recitative singing with some rare individual melodic phrases that never receive any further development, Ravel was inspired, on his own admission, by Marriage, an unfinished and rather enigmatic opera fragment by Musorgsky, based on Gogol's comedy. What, exactly, Ravel might have taken from this fragment, besides the recitative principle (which was already available in both Dargomyzhsky and Debussy), is unclear. Neither in Ravel's correspondence nor in the accounts of memoirists are there any indications that Ravel was acquainted with Musorgsky's manuscript score. But Marriage had been published in an edition by Rimsky-Korsakov that monstrously distorted the composer's conception. Rimsky furnished his edition with notes on the supposedly "unperformable" and "hardly audible" rhythmic complications and "bad-sounding harmonies" in Musorgsky's manuscript, which he allegedly corrected (the way Turgenev corrected the meter in Tyutchev's "A Dream at Sea"). In the same notes, Rimsky gives examples of Musorgsky's rhythmic and harmonic finds, from which it is immediately clear that in this unfinished fragment, Musorgsky was trying to work out a rhyth-

5 Actually, Shostakovich omitted this episode from Leskov's story.-Ed. 
mic design reminiscent of Stravinsky's Les noces, and that the harmonies that offended Rimsky-Korsakov, based on parallel seconds, came near to surpassing Béla Bartók. Rimsky made short work of all this "heresy," abbreviating and squeezing the rhythm into customary measures of threeor four-quarter time and turning the seconds into grace notes, following all the rules of textbook harmony. Thus, while it is tempting to trace the harmonic spice and the free rhythmic declamation in L'heure espagnole back to this evidently revolutionary bit of Musorgskian innovation, the simplified version to which Ravel had access, Rimsky's, does not support such a notion.

By the time Ravel returned to the operatic genre, about two decades after L'heure espagnole, his ideas about musical theater had changed fundamentally and he was attracted to altogether different tasks. In L'enfant et les sortilèges, the melodies are assigned to the human voices, with the orchestra given a more modest role-though even here Ravel's fabulous orchestra has brilliance and sparkle to spare. The libretto of Ravel's second opera was created in collaboration with the remarkable writer Colette. A subtle stylist, a profound student of the human heart, Colette was for some reason considered a boulevard romancière in prerevolutionary Russia. In Soviet journalism and criticism she is either ignored or hushed up, despite the wide popularity of her works in the West and the growing, tender love both for her books and her person among a very wide circle of readers in France as well as the USA, England, and especially Germany.

In the libretto she wrote for Ravel, Colette made use of the conventions and devices of French children's stories to create, in an ingenious form, an interesting and profound allegory of an eternal theme that has in recent years taken on a keen timeliness: the theme of the generation gap, of mutual incomprehension between "fathers and children," ${ }^{\prime}$ the unwillingness and incapacity of the younger generation to appreciate the spiritual, moral and social values of their "fathers." The bored little hero of the opera is a boy who has been sat down to do his homework, who is not allowed to run free, not allowed to torture animals for fun. During a short episode in which his mother admonishes him, the boy is silent.

6 A reference to the title of Ivan Turgenev's famous novel Ottsy i deti (in English usually rendered as Fathers and Sons after Constance Garnett's nineteenth-century translation) - so famous that the author did not have to be named.-Ed. 
To her received truths he makes no objection: he knows he will not be understood. Then comes an explosion: the child is left alone and, in order to feel free, gives himself up to an orgy of destruction and vandalism-he breaks dishes, douses the fire in the hearth, cuts the wallpaper, smashes the wall clock, tears his books and attacks his cat and pet squirrel, who run away in terror. All this is accompanied by a joyful cry: "Hurrah! To hell with homework! To hell with chores! I am free, free, bad but free!"

In L'heure espagnole, the action proceeded without interruption. Colette's libretto is built in a novel episodic form, an "opera with sliding drawers": in a long succession of individual episodes wherein the broken things and wounded animals pour out their feelings, the little hero gradually realizes the nature and consequences of his "revolt." In the first half of the opera, Colette somehow hit upon one of the themes of contemporaneous Russian poetry: the theme of "insurrection of things," the refusal of inanimate objects to serve the degraded purposes of mankind, as developed by Khlebnikov (The Crane, Marquise des S.), Mayakovsky, and Marina Tsvetaeva (Poem of the Staircase). The furniture refuses to hold the boy when he grows weary from destruction. The armchair and couch suddenly come to life in a cumbersome duet in the tempo of a sarabande. They announce their refusal to serve the little barbarian, while in the orchestra heavy chords in the piano and sliding trombone and cello glissandi create the impression that in the room the floor has tilted and all the furniture is threatening to slither off in some direction.

After the comically pompous furniture, the broken clock takes its turn-an aria for baritone. This is one of the most convincing examples of musical psychology in Ravel's operatic output. If in L'heure espagnole the composer was able to develop complicated psychological designs using Franc-Nohain's puppet-like characters, in his second opera, with the help of Colette, he imparts the same compelling humanity to inanimate objects, plants, and animals. The clock's part is an extended, and in its own way tragic, portrait of a certain type of functionary. Paramount in the life of this clock-man is order and utility. For long years the clock has honorably served humanity: it announced when it was time to get up, when to lie down, and when to receive one's nearest and dearest. The mechanical, swinging-pendulum rhythm of the aria gradually gives way to broad vocal lyricism - the clock's motives, you see, were altruistic; the clock wanted its ticking to accompany the boy into a bright and happy future. The same 
boy who went and broke the pendulum! The clock has come into collision with an irrational and destructive force, to which it reacts with outrage, grief, but mainly incomprehension ("but all I ever wanted was his happiness!"). In despair at running down, the clock stands itself in the corner to hide its shame and pain from the world, and the music illustrates its collapse with fitful rhythmic irregularities.

After the intricately devised episode with the clock (scarcely within a child's grasp), there follow episodes of a more diverting nature. The grotesque duet of broken dishes-a brash English porcelain teapot (a tenor, singing in a mixture of English and French) and an elegant Chinese teacup (a mezzo-soprano, holding forth in an arcane patois that is supposed to sound Chinese but that is based on guttural quasi-Japanese words like "hara-kiri" since, as the teacup notes, "either way it's incomprehensible") - is a colorfully orchestrated twenties-style foxtrot. The modish and sophisticated melody of the teacup (later repeated by the trombone in a stratospherically high register) distantly recalls the as-yet-unwritten Boléro. The monstrously difficult fioritura aria for the fire (coloratura soprano), enraged at having been doused by water from the teapot, recreates the brilliant cabalettas from the heyday of Italian bel canto. The chorus and dances of the separated shepherds and shepherdesses on the wallpaper the child has ripped are musically simple and ingenuous; yet if you listen closely to their delicate pastorale ("the naughty child has forever spoiled our tender tale"), you will find, unexpectedly, a lump in your throat.

Terrified by what he has seen and heard, the child seeks an answer in his books, from which he has just ripped out some pages. From a volume of German fairy tales arises a princess-his favorite heroine. She is in the clutches of an evil sorcerer, but the boy knows the tale by heart: to the aid of the princess leaps a valiant knight; in the orchestra the hoofbeats of his horse draw nigh, already the victory trumpets resound.... But at this point everything comes to a halt, because the pages describing the rescue of the princess have been destroyed. Now nothing can save her and in despair the little hero sees the shaggy paws of the sorcerer drawing her down beneath the earth, forever. And in his arithmetic workbook the tables with the answers have been destroyed and a chorus of nasty little numbers (children's voices) unloose on the child torrents of monstrous fractions, meaningless snatches from typical arithmetic examples ("so- 
and-so bought such-and-such"), and obviously wrong calculations. The irrational evil in mankind is equally disastrous in the realm of dreams and fantasies (fairy tales) and in the logical world of applied mathematics.

The storm of numbers gives way to silence. The boy is stunned and staggered. The cat returns, and the child who had just been torturing it now throws himself upon this living being to unburden his soul. But the affronted tomcat has no time for its owner: he is now involved in a romance with a white kitty. If this episode is similar to a corresponding one in Chaikovsky's Sleeping Beauty, the music of this cacophonous catty duet, strangely enough, goes back to the slow movement of the "Pathétique" Symphony-the same faltering waltz-like pattern in five-beat measures.

The cats' duet serves as a transition to the second half of the opera. The action moves from the room into a garden, from a world of humanized objects to a world of humanized living creatures. The orchestral sonority immediately grows warmer as if receiving a blood transfusion, an effect achieved through a simple stroke of genius: the whole string section enters, having throughout the first half played only pizzicato, a few soloists apart. Against a background of long drawn-out phrases from the newly lyrical string orchestra, depicting a warm summer night, Ravel musically paints the chirping of crickets and the warbling of a nightingale. An offstage chorus, singing in an invented frog language (Colette's ways coinciding here with those of the Russian Futurists!), depicts distant croaking in a marsh. But now the child appears, showing that mankind treats nature no better than his own things. The trees (male chorus) drip resin from the wounds left by the boy's penknife, a dragonfly (contralto) laments a companion the boy has pinned, and a male bat despairingly rushes about feeding the young whose mother the child had killed with a well-aimed rap of his stick. A long ballet episode ("Dance of the Tree Frogs"), a sparkling waltz that develops and varies the melody of the pining dragonfly, ends in the scene of the boy's culminating epiphany.

A stupid tree frog (tenor buffo) hops beneath his feet, and the pet squirrel that escaped at the beginning of the opera warns it from the tree: "What about the cage? He'll put you in prison, just like me, you moron!" The shaken child tries to defend himself, saying that he kept the squirrel in a cage because he loved it and wanted to admire its agility. The squirrel's arioso in reply (mezzo-soprano) is the most remarkable page in the score 
for its depth, pathos, and expression. It is a terrible thing to introduce chaos and destruction into the constructive efforts of others (the episodes of the clock and the arithmetic workbook), terrible arbitrarily to separate lovers (shepherdesses on the wallpaper, the princess, the dragonflies), terrible to kill a living creature for fun (the bat, the trees). But the most shattering pages of this ostensibly amusing children's opera speak of one of the most horrible manifestations of our age: depriving others of their freedom under cover of humanitarian or progressive sentiments. One of the greatest composers of the nineteenth century had expressed this theme with the same zeal and clarity-Beethoven in Fidelio. The writer of these lines was present when a German journalist, listening to L'enfant et les sortileges on a record with text in hand, having heard the squirrel's arioso in an excellent performance by the French singer Solange Michel, left the room, her lips trembling. "That's how it was with us under Hitler," she remarked later. It is unlikely that even the most detailed musical analysis could show exactly how Ravel achieved such a profound effect in this arioso, which lasts only about four pages in the score and conforms outwardly to the form of a slow Boston waltz.

In the opera's finale the little hero sums up what he has learned from the things and beasts. He binds the squirrel's injured paw and to the strains of a serenely glowing chorus slowly goes back home. Right before the curtain falls, he pronounces a single word, in which is expressed his whole understanding of the necessity of civilization, tradition, tolerance. That word is "Maman." Over the chorus the figures played by two oboes, which had depicted his boredom and disgust at the opera's beginning, now sound pleasant and attractive.

The operas of Ravel are brilliant in form, profound and humane in content. Their treatment of difficult and problematical aspects of human life in a glittering and seemingly playful tone is high artistry, artistry devoid of false pathos or pseudoprofundity, comparable to the similarly exalted yet sunny works of Goethe, Pushkin, and Mozart. And yet Ravel's operas are regarded by most opera houses as superfluous. On American television every year they show the utterly banal children's opera Amahl and the Night Visitors by Menotti; in Russian theaters they go on reviving The Snow Maiden, crude in music and libretto alike (a few individually delightful turns notwithstanding); and in Germany at yuletide the cozily philistine opera Hänsel und Gretel reigns-even though, whether in 
terms of artistic merit or in terms of musical beauty, these now traditional opuses are worlds beneath the fabulous second opera of Ravel. And needless to say, in terms of vocal and instrumental delights, L'heure espagnole far exceeds practically all the one-act operas in the established repertory, like Pagliacci, Cavalleria rusticana, or the melodramatic, tawdry Salome of Richard Strauss. What's the problem? Obviously, the problem is that their lightness of craft and playfulness of manner have prevented critics and public alike from sensing the full depth and significance of Ravel's operas. Just so, readers of Pushkin's time immediately went into ecstasies over Boris Godunov, while The Bronze Horseman and The Little House in Kolomna were for decades looked upon as unassuming trifles. Just so, the whole nineteenth century either never noticed or took offense at the most humane of Mozart's operas, Cosi fan tutte, and only in the twentieth did people understand that the libretto of this opera, which had offended Beethoven and Wagner with its "immorality," was in fact a polemical and humanitarian tract on behalf of tolerance and the rights of women. One can only hope that the recent radio broadcasts of Ravel's operas will lead to a reexamination of received ideas about these two most original and significant creations of the twentieth century. Just as a fresh reading of the Cosi fan tutte libretto led to a new appreciation of the opera's magnificent music (which had seemed to Wagner, blinded as he was by Victorian moralism, to be weak and ineffective), a deepened and freshened understanding of L'heure espagnole and L'enfant et les sortilèges must in the future reveal to listeners all the perfection and iridescent brilliance in these two scores by Ravel.

This lovely piece is SK's only Russian-language essay on music, and its allusions and choice of examples for comparison show him very much in the light of a Russian writer in exile writing for his peers. Among his papers that are now a part of the collections of the Bancroft Library at the University of California, Berkeley is a previous translation by a graduate student of his, Charty Bassett, from which we have adopted the delightful substitution, at the end of the first paragraph, of Lolita for Andrei Bely's Kotik Letaev, SK's original example of a work about-but not for-children. Some references that might be arcane for non-Russian readers have been clarified in footnotes. 